\title{
The Child - A View Across the Tweed
}

The Rt. Hon. Lord Mackay of Clashfern

For any system of law there can be no more important duty than insuring that those who are least able to fend for themselves in the community are adequately protected. The three main groups within this category are the sick, the old and the young. On this occasion I wish to say a little about the law and its relationship to children because I believe that this, and its many facets, is one of the most pressing and persistent problems that we face.

It would be reckless for me to try to provide a comprehensive over-view of all the law about children, whether in the context of crime, or of divorce, or of neglect. Instead, I wish to look at the way in which Scots law and the Courts in Scotland have attempted to grapple with these problems and how it is now proposed to amend the law in England and Wales. There is, therefore, a certain ambiguity lurking in the title of this paper, depending on the viewer's location.

The Social Work (Scotland) Act 1968, in section 32(2), sets out the conditions on which a child may be made the subject of compulsory measures of care. They are:-

"(a) he is beyond control of his parent; or

(b) through lack of parental care he is falling into bad associations or is exposed to moral danger; or

(c) the lack of care as aforesaid, is likely to cause him unnecessary suffering or seriously to impair his health or development; or

(d) any of the offences mentioned in schedule 1 of the Children and Young Persons (Scotland) Act, 1937 has been committed in respect of him or in respect of a child who is a member of the same household; or

(e) the child, being a female, is a member of the same household as a female in respect of whom an offence which constitutes the crime of incest has been committed by a member of that household; or

(f) he has failed to attend school regularly without reasonable excuse; or

(g) he has committed an offence; or

(h) he is a child whose case has been referred to a Children's Hearing in pursuance of Part V of this Act."

*The Lord High Chancellor of Great Britain. The Child \& Co London Lecture 1988, printed by kind permission of Lord Mackay of Clashfern and Child \& Co.. 
Much of this will have a familiar ring to English lawyers. Implicit in our statute is the idea of the child in trouble. A child may get into trouble in many different ways and in practice the different grounds for compulsory measures of care are likely to run into one another. Truancy may indicate that the parents have insufficient control. It may lead to association with undesirable acquaintances and to the commission of crimes by the child. Similarly, a child who grows up in a household where he or she is the victim of crime and even, most horrifically of all, of sexual abuse, is unlikely to develop the moral strength which we would all hope that all parents would manage to instil into their children.

The major existing distinctions between the situations north and south of the Tweed are the institutional arrangements for putting the substantive law into effect.

I hope it may be useful if I describe very briefly what those arrangements are in Scotland. There the decision about what should happen to a child who is, arguably, in need of compulsory measures of care, is taken by what is called a Children's Hearing. For these purposes the Secretary of State appoints what is called a Children's Panel which is a large body of people who, rather like Juvenile Court Justices in England and Wales, can be considered to have the right qualities, not excluding, I hope, sound common sense, to make such decisions. Three such people from the panel constitute a Children's Hearing and there must always be a man and a woman from the panel at each hearing. The Children's Hearing is always conducted in private and with the minimum of formality. This is possible because a Children's Hearing does not hear any kind of dispute about whether the grounds for considering compulsory measures of care are made out. Thus the Children's Hearing can approach the issues it has to resolve in perhaps a more constructive way than might well be possible if it had to decide contentious questions of fact. If there is a dispute about whether the grounds are made out then the matter is referred to the Sheriff for him to decide that issue. This appears to $m e$ to be a valuable separation.

In connection with the hearing before the Sheriff the contentious issues of fact can be investigated and decided in very much the same way as they would be in an ordinary court. But when it comes to disposal the Children's Panel take over and, as I said, the whole atmosphere is much less formal and it is possible to have a round table discussion in which the Panel can hear at the same table the views of the parents, the social worker, the views of the teacher from the school and, possibly, foster parents if there are foster parents involved and perhaps other people with an interest - so that there is not the same sort of insistence on people being interested as parties before a Court as there would be at the earlier stage if there is such an earlier stage.

The second institution which is an essential feature of the Children's Hearing system, which I believe does not have a direct parallel south of the border, is the. Reporter. The Reporter is an official appointed by a local authority whose function it is to decide whether a child should be brought before a Children's Hearing. The 
Reporter's discretion is very wide. Under section 39 of the Social Work (Scotland) Act 1968 he is given power to arrange a Children's Hearing, or to refer a case to the local authority with a view to their making arrangements for advice, guidance and assistance to the child and his family, and he is given (and I think this is quite important) explicit power to take no further action on the case. So Parliament has entrusted him with a very very wide discretion indeed, and I think it very unusual to have a provision of that kind for a public official namely that he should have power to take no further action at all on what has been referred to him.

This discretion is exercised actively and frequently. Of the 36,000 or so cases referred to Reporters in 1986 no action was taken in about half of the cases. Now when I say "no action" of course I am referring there to action which can be identified. I think it highly likely that in many of those cases recorded as cases in which no action was taken, the Reporter on hearing of the case has had some contact for example with the child's parents and has been satisfied after talking with them, that once they have known about the problem the problem is, perhaps, not likely to be repeated. It is quite a striking compliment to that system that it seems to have operated in about half of the referred cases.

The Reporter in many ways functions, in respect of the Children's Hearings, as does the Procurator Fiscal in respect of the Criminal Courts. The Procurator Fiscal in Scotland corresponds perhaps somewhat roughly to the Crown Prosecutor recently established in this country although the Procurator Fiscal has a somewhat longer history in Scotland than does the Crown Prosecutor in England. Although Reporters are not necessarily legally qualified the parallel with the Procurator Fiscal is made even more marked by the fact that three quarters of the cases which are brought before the Children's Hearings allege that the child has committed an offence. So although the offence heading is embedded in quite a long list of grounds for referral in respect of numbers of cases it is the most important one, in terms of numbers.

In one respect, however, the Reporter is more independent, even, than the Procurator Fiscal in his decisions. The Procurator Fiscal is responsible to the Scottish Law Officers, and ultimately through them to Parliament, whereas, as far as I can tell the Reporter is responsible only to himself. It is remarkable, and a great tribute to the integrity and ability of the men and women who are Reporters, that in an age which distrusts discretion vested only in officials, they have been so successful.

There has been one major change in the institutional arrangements since the 1968 Act. English lawyers will recognise it, although under a different name. The Sheriff, and the Children's Hearing, have the right to appoint what is called a "Safeguarder" where there may be some conflict of interest between the child and the parents. In England and Wales, I think he or she would be called a "Guardian ad litem". But in Scotland, as you know, we like to go for simpler expressions. The function of the Safeguarder is broadly the same as that of the Guardian ad litem in care proceedings in this country. 
But it is not just through the systems of juvenile justice through the Children's Hearing in Scotland that a child may come into contact with the law. Large numbers of children are, unhappily, the helpless victims of family breakdown and their welfare has to be taken into account when the Court comes to deal with the consequences. The Courts, in Scotland, now have wide powers to do what is best for the children. Procedural and technical obstacles have been almost entirely swept away. In Scotland now divorce is available through the Sheriff Court which has made proceedings a great deal more accessible than they were. One controversial question in recent years has been the application of section 8(1) of the Matrimonial Proceedings (Children) Act 1958 which, again in wording which will be familiar to English lawyers, restricts the power of the Court to grant a decree unless it is satisfied that satisfactory arrangements have been made for the care or upbringing of the children or that it is impracticable for the parties to make such arrangements. The criticism has been that this places a duty on the Court which, on the limited evidence available to it, it can perform only in the most perfunctory way. However, more recent research on satisfaction hearings in Scotland, I gather, suggests that some of the earlier fears were exaggerated and that some of the solutions canvassed, such as many more independent reports to the Court on the situation of the children, were unnecessary. A report by the Scottish Office Central Research Unit, for instance, suggested that in 60 per cent of cases there was adequate information for the Court and in the other 40 per cent a suitable level of information could be obtained simply by improving the content and format of the documents which the parties are required to lodge with the Court, and by calling for reports in a very limited number of cases.

The question of the use of reports in children's cases leads to the broader question of how far a court dealing with children's welfare should be inquisitorial in style. I think it is fair to conclude that where the parents are parties to the case there is very little by way of movement towards an inquisitorial system. In Scotland the practice of the judge's interviewing the children concerned in a divorce case has, I believe, not found a great deal of favour with the appellate courts. They pointed out the dangers possibly involved in that. The Children's Hearing is perhaps the closest to an inquisitorial proceeding we have, although the presence of the Reporter and the absence of dispute over the grounds on which the application is brought tend to lend themselves, as I said earlier, somewhat to this approach. It may be of interest also to note, in this connection, that the Court of Session has also taken the view that it can be justifiable for the Children's Hearing to withhold certain documents it has from the parents. As they put it: "The principles of natural justice must yield to the best interests of the child." This is obviously a matter that was the subject of a good deal of contention, but it is a reflection of the fact that the Children's Hearing is not, in the ordinary sense, a court hearing with parties and is the sort of body which should be given a considerable amount of flexibility in the rules which it applies.

On this occasion, I need not detail the existing law relating to children in 
England and Wales beyond saying that whilst it has some strong similarities to that in Scotland, for example, in the grounds for care proceedings in section 1 of the Children and Young Persons Act 1969, it will by now be apparent, if it was not already, that there are clear divergences.

Looking to the future, the last 3 years have seen major reviews of child law. On the public law front of child care the DHSS published a consultation document, the Reviem of Child Care Law, in late 1985 . It was followed in early 1987 by the White Paper on Child Care and Family Services ${ }^{1}$ which amongst other things set out the Governmment's conclusions on the protection of children at risk and the role of the courts in that task. At the same time the Law Commission, which had provided its specialist services to the DHSS in its work, was reviewing on its own behalf private child law in the areas of guardianship, custody and wardship. The Law Commission has now finished consulting on their four Working Papers and we eagerly look for their report as soon as it is ready. ${ }^{2}$ Finally, we are awaiting the report from the Cleveland inquiry. This coincidence represents, in my view, an historic opportunity to reform the English law in this area into a single rationalised system as it applies to the care and upbringing of children.

On the public law side, we know from the White Paper that there is no present proposal to follow the Scottish system. Indeed, in some ways, such as the grounds for making care and supervision orders, the proposals will create new differences. Thus in England and Wales the grounds in future, assuming the White Paper proposals are put into legislation, will look directly to the reasons why state intervention is required, thus moving away from the descriptive or symptomatic approach in the existing Scottish and English legislation. Hence it is proposed that before a care or supervision order can be made the court should be satisfied that there is harm or likely harm to the child resulting from an absence of a reasonable standard of parental care, or the child being beyond parental control and, in respect of both, that the order proposed is the most effective means of safeguarding and promoting the child's welfare. So that there will be first of all the question whether some form of order is needed having regard to the apprehended harm to the child, and then secondly, what form of order is appropriate in the particular circumstances of the case. However, in a purely English context the movement towards a single integrated law of children is apparent. I mean by that that the mere fact that England in this is diverging from Scotland is not, in any sense, to be regarded as other than a good development. It is important in my view, that the Law of England and Wales should itself be an integrated system, and if it turns out to be a good one - who knows, but in due course the Scottish law might follow it. Thus it is proposed that where the court concludes that an order giving custody to a private individual would be appropriate, that should be available to the

1. Cmnd. 62 (1987).

2. See Law Com. Working Papers, No. 96 (with Supplement), Review of Child Law: Custody (1986); No. 100, Care Supervision and interim orders in Custody proceedings (1987); No.101, Wards of Court (1987). 
court as an alternative to care or supervision and that there should not be a situation in which you get one type of proceedings and are not able to get that type of order except in these proceedings and if you want a different type of order you have to go in for different proceedings altogether. This is the suggestion of the White Paper and I believe that the response to it generally is to think it a good development. Or again, whilst not following the Scottish model of Children's Hearings, the White Paper makes it clear that there are to be changes to procedure in care cases to move care proceedings "away from the quasi-criminal model towards a civil model thus bringing private and public child law closer together". Yet a further example of the closer integration of public and private child law can be found in the Government's intention to require the same grounds for care and supervision to apply in family proceedings as in proceedings brought by local authorities seeking such orders.

As regards private law, we are still, as I say, awaiting with interest what the Law Commission will propose. However, their close liaison with DHSS and much of what they have said in their Working Papers suggests that they too hope that we will seize this opportunity to bring public and private child law together into a comprehensive, comprehensible and consistent code. In this work we must all wish them well and hope that the results will come soon.

Finally, there is the Cleveland inquiry. I am not in a position even to guess what recommendations for change may emerge from that inquiry. So far as the Law Commission is concerned, as I said, there are some materials available from which a good guess may be possible, but so far as the Cleveland inquiry is concerned, I am not in that position. If such a word can be used of so unhappy a topic, its findings will, I hope, prove opportune by becoming available at a time when they will be dealt with in the broad context of child care and welfare in the law.

Having spoken of Children's Hearings in Scotland and the Reporter you may be expecting some news from me on the proposals for a family court in England. Well, it is difficult to give news about a topic which is so differently understood by different people. Everyone who uses the phrase appears to understand it somewhat differently. But I think it would be fair to say that the Government is continuing to work on the subject but it would be premature to reach any very final conclusions at this stage. At the heart of family law there is rightly the concern for children. Until we have settled the substantive law in that respect, and by this I mean the public law discussed in the White Paper, the private law to be discussed in the Report from the Law Commission and the related matters to emerge from the Cleveland enquiry, and have a clear view of questions and tasks which the courts will have to undertake, it would be rash, in my opinion, to decide what changes may be necessary to the constitution of the courts and their structure to ensure that they can effectively apply the intended new, comprehensive code of child law. It surely must be right to know first of all the nature of the questions that are likely to arise from the substantive law as it applies to particular cases before you seek finally to devise a structure to obtain the answer. 
From what I have said, you will see that a view across the Tweed, whether from its northern or southern bank, presents the Scottish or English lawyer with a mixture of recognisable landmarks and highways set in an unfamiliar landscape. Given the opportunity of a guided tour I would hope that each might learn lessons from the other whilst accepting that there are differences in the cultural, social and historical geography which may lead to different solutions being found to different problems on both sides of that great river.

It is surely very remarkable how the Scottish and the English systems have continued as such distinct legal systems for the 280 years or so since the Union of the Parliaments. This is a source of richness in the legal culture of the United Kingdom which I greatly value as the opportunity it gives for improvement of each system by competitive study is a great advantage which I believe will continue as far as one can see into the future. 